\title{
The constitutional politics of crisis in
}

\author{
Europe \\ A Review of: Poul F. Kjaer \& Niklas \\ Olsen. Critical Theories of Crisis in \\ Europe: From Weimer to the Euro. \\ London-New York: Rowman \& \\ Littlefield, 2016
}

Pablo Holmes (holmes@gcr21.uni-due.de)

Centre for Global Cooperation Research, Duisburg/ University of Brasilia, Germany/ Brazil

Since the beginning of the 2010s there has been an array of prolific literature concerning the reasons and consequences of the financial crisis that spread over the world economy since late 2008, developing into the Euro crisis in the following two years. Meanwhile, the global political landscape was shaken by events that would seem unimaginable one decade earlier.

The rise of new radical and populist political movements, in Europe and elsewhere and the emergence of new forms of social mobilization and protest that seemed to challenge the role of political parties and parliamentary democracy for democratic constitutional regimes were enough to cause a shift in the theoretical reflection about the crisis. These reflections now seem to go way beyond the institutional reasons for the breakdown in the banking system that was at its origin. Indeed, the crisis was no longer an economic and mainly financial - crisis; it came to be seen as a constitutional crisis.

This shift is the main theme of the book organized by Poul J. Kjaer and Niklas Olsen: a reflective attempt towards a sociology of the European Constitutional Crisis of our time (with clear implications for a broader understanding of the social structure of constitutional crisis in today's world society). In order to do that, they proceed in a quite creative way: they use different disciplinary perspectives to advance a broad (critical) theory of the current crisis. Political philosophy and political theory, history, sociology of law and of constitutions, political and constitutional theory build a compound in which each part offers a different building block.

The first section of the book deals with the concept of crisis and its evolving meaning in contemporary politics. David Ruciman and Janet Roitman reconstruct the concept philosophically, pointing out its problematic ubiquity and its consequences for contemporary democracies. Following an argument already discussed by Reinhardt Koselleck (Koselleck, 2006) and Niklas Luhmann (Luhmann, 1997, pp. 1109-1128), Ruciman remembers that, by becoming ubiquitous, the idea of crisis loses its critical content. In fact, it becomes 
inflationary and thus naturalized: no one knows anymore what the dangerous threats really are and which deciding moments are truly turning points in history, the two elements that define the existence of a crisis. On the other hand, this ubiquity is quite useful, since democracies may use it in order to remain sensitive to any potentially dangerous event, making a crisis from almost everything. Therefore, the political system becomes also able to focus on different issues, confronting potential threats before they become really destructive. On the other hand, a problem arises when the continuous shift of attention from a new upcoming crisis to the next prevents the political system from taking the decisions that can adequately tackle their structural causes.

Janet Roitman follows a similar path, arguing however that a theory of crisis needs to advance further than the mere diagnosis of a "crisis ubiquity". She proposes a secondorder observation of the "crisis discourse". Taking seriously how events are framed as a crisis is essential for understanding how different political actors construct their social experience. Therefore, a critical theory of crisis cannot be satisfied to point out that the concept has lost its meaning: it must understand that the concept is central for how politics is made and, hence, it must be part of any attempt to understand the way history unfolds.

The second section attempts to reconstruct the ideological landscape at the roots of the explosive European constitutional crises of the 1930s, identified with the failure of the Weimar Republic and the rise of different forms of Authoritarianism in Central and Eastern Europe. John P. McCormick goes back to the authoritarian political philosophy developed by Carl Schmitt and Leo Strauss, arguing that their divergence was founded on the meaning of morality for human life and the consequences of individualism for modern society. In the end, his argument, in line with some studies on the new right-wing populist movements (Elchardus and Spruyt, 2014), points out the lack of moral unity and the increasing sense of decay of common social morality as one of the main reasons for the rise of totalitarian and authoritarian movements, in the 1920s and in today's European landscape.

Following a similar thread, Balázs Trencsényi argues that the anxiety produced both by the feeling of being left behind and by the disruptive dynamics of market economy was at the roots of conservative intellectual movements emerging in Central and Eastern Europe in the beginning of the twentieth century. For him, new intellectuals translated the frustration of a supposed backwardness of Eastern European countries into a sense of moral superiority in the face of Western "moral decay". These movements would still be important to understand the rise of populist movements and leaders such as the Fidesz and Viktor Orbán, in Hungary.

Niklas Olson looks at the concept of "consumer sovereignty" and how it was created to legitimize the liberal agenda in the interwar period, as the rise of the social question and labour conflicts blighted the reputation of liberal ideology from the end of the $19^{\text {th }}$ century. Connecting markets and liberal democracy, the claim was that a market economy had an intrinsic democratic content, given that consumers were for the economy nothing less than voters with equal rights as they make choices in the markets. Although its success has been limited at first, given the advance of Keynesian ideas and the spread suspicions towards nineteenth-century-like capitalism even among liberals, this idea has been re- 
newed after the Second World War by a transnational articulation of intellectuals and economists organized under the Mount Pelegrin's Society. These networks succeeded in reshaping state regulations after 1970 and achieved a broad hegemony in fiscal and monetary policies after the 1990s. Olson does not explicitly say that, but it is clear that the concept of consumer sovereignty also became a basic cornerstone of the European constitutional structure, deeply shaping European competition law, its Central Bank's monetary policy and, beyond that, the very concept of individual rights at the basis of European political unity.

The third section revisits the evolution of the European constitutional model. Chris Thornhill argues, as he has been doing in the last decade (Thornhill, 2011), that the crisis of the Weimar Republic, common to other European states, was caused by the expansion of the political system (hyperpoliticization) as a tool for producing societal inclusion and modernization. For him, the attempt to produce a modern nation through social inclusion was pursued, in the case of the Weimar model, through the constitutionalization of social rights, mainly in the form of labour law. This allowed for the emergence of a political model that concentrated power in the hands of a few economic corporations and national unions, expanding the influence of the political system to other sectors of social life. Despite its initial inclusionary intentions, the concentration of power of the corporatist constitution model gained an exclusionary impulse as society became more and more subject to the constraints produced by its "political core". The consequences were to be seen in the authoritarian regimes that emerged in many European countries after the 1920s. The corporatist model was thus succeeded by a neocorporatist arrangement, limited by a strong structure of individual and human rights, that was also reflected in a wide process of legal internationalization.

Similarly, Ruth Dukes argues that labour law was at the roots of the social conflicts taking place under the Weimar Republic. For her, in that context, labour law was mainly conceived through the lens of a class struggle paradigm: as an opposition between capital and labour. She reconstructs its history after the Second World War and adverts that its founding opposition has been gradually replaced by the opposition between insiders (standing in a protected labour relation) and outsiders (the so-called precariat outside protected labour relations). This new opposition would strip labour conflicts from all their political transformative potential, by playing workers against workers in a labour market in which the power of capital came to be seen as a set of naturalized given conditions that cannot be touched.

The section ends with Poul Kjaer's contribution, in which he recounts the European constitutional history as a shift from corporatism to governance. Following Thornhill's definition of corporatism, Kjaer goes further, identifying a reorganization of the state/society relations beginning in the 1970s through new technologies of government, based on adaptation and efficiency. Accordingly, the state would have shifted its focus from direct conditional regulation of social relations to a more fine-tuned adaptative learning of selfregulatory social dynamics. Such a shift poses however challenging quests over the legitimization of power and regulation, a problem at the very core of the actual European constitutional crisis. Interestingly, Kjaer asks whether these changes would not mean a 
sort of refeudalization of society through the naturalization/depoliticization of law and regulation.

The fourth section of the book focuses more specifically on the underlying relation between the Euro crisis and the Constitutional Crisis of the European Union. Christian Joerges recounts the origins of the European Project as the result of a political victory of German Ordoliberalism. The cornerstone of this project would consist of an ever-closer union of the European markets through a process of legal integration. For Joerges, the Euro was however a break with this foundational project, as the introduction of the common currency without the creation of a fiscal union gave place to a new dimension of constitutional conflicts that could not be solved through the sole means of legal integration. If Europe had always had horizontal conflicts between member states and vertical conflicts between the Member States and the Union, the Euro crisis added a sort of diagonal conflict to that. European monetary policy "is neither supreme to fiscal and economic policies", since the latter remain attained to the national level, "nor does it 'preempt' the exercise of national powers", since member states still can follow their own directives and objectives in these matters (p. 150). The European monetary policy aims at the stabilization of the currency, while it has no means to bind the economic and fiscal policies of member states in a coordinated manner. This leads to a situation in which it is impossible to tackle possible conflicts between the aims of different levels of governance through the means of general legal rules. The only way out of this contradiction was then the divorce between European constitutionalism and the rule of law. Accordingly, the ECB and the (unconstitutional) Eurogroup were functionally forced to resort to ad hoc (fundamentally illegal) strategies in dealing with the debt crisis of the European peripheral states. Therefore, European crisis management has been put in a crisis itself, wrapped in a paradox between the necessary decisions to keep alive the Union and the "rule of law" structure that was its cornerstone.

Indeed, the release of informal power can also be seen, although in another form, in the way in which the EU deals with the so-called "rule of law crises" taking place in countries governed by illiberal populist movements, such as Hungary, Poland and Romania. This is the theme of Jan-Werner Müller's contribution. He describes how the European commission abstained from applying sanctions against national governments pursuing constitutional reforms and policies that clearly violated basic principles of minority protection, electoral equality and democratic accountability of executive powers. These sanctions were clearly provided for by the European treaties (Article 7, TEU) as a protection of the main values of the Union, such as democracy and human rights (Article 2, TEU). By deciding to frame these violations as a "rule of law crisis", the Commission followed a legal path that avoided open conflicts between the Union and member states, describing violations as part of a "governance crisis" rather than a fact demanding clear legal and political decisions. This step has only strengthened the argument made by the undemocratic governments of those countries, according to which the Union is governed by the informal power of an illegitimate transnational elite without any clear democratic authorization. For Müller, the violations should have been tackled from the beginning as they genuinely are: as "rule breaking" acts that demanded action by the European Council in accordance with the provisions of Article 7. 
Joerges' diagnosis is in a certain way enlarged by Hauke Brunkhorst's description of the Euro crisis as the trigger of a legitimization crisis of the European project. For him, the end of the happy marriage between ordoliberalism and rule of law represented a victory of a new form of turbo-capitalist management unbound from any form of democratic control. In other words, the release of huge amounts of informal political power - now in the hands of the bureaucracies in the ECB and the Eurogroup - makes it even more difficult for the weak European public to engage in processes of collective and democratic decision making. Besides depleting the capacity of democratic elections to influence relevant economic decisions - as in the Greek, Italian and Spanish cases - the constitutional shifts after the Euro crisis also closed the range of alternatives made available to the public through national elections, creating multitudes of European citizens stripped of any capacity to influence large political processes - in the core as well as in the periphery of the Union.

The fifth and last section of the book turns its attention to the future possibilities facing the peoples of Europe, be it in the form of resistance and struggle for democratic reconstitutionalization, or be it in the form of a democratic decay thanks to the rise of an anti-modernist right-wing. William Scheuerman offers the reader an interesting interpretation of the pacifist civil disobedience tactics of the North American civil rights movements as an alternative method of resistance in the European case. He notes that the unleashing of managerial informal power for European transnational bureaucracy does not represent exactly a kind of open state illegality. Under conditions of emergency, such as that of the Euro crisis, governments often resort to some sort of extralegal devices to advance the goals of sovereignty and political stability. This is however not the only form of extralegality. Also, the governed can resort to extralegality when they offer specific forms of popular resistance. Extralegality may not be confused with illegality, because it aspires to be or to become the legitimate form of legality. Of course, there are differences between the extralegality of the governing and that of the governed. The former is usually claimed to be a necessary way to guarantee social order as a broader goal. The latter takes mostly the form of resistance against political ruling perceived as unjust or illegitimate. Governmental extralegality can make use of the means of the state, such as organized violence and legal tools to advance its goals. Governed extralegality can only assume a form of pacific civil disobedience. This must be so because civil disobedience is always on the edge of becoming part of plain illegality. The lessons of Martin Luther King serve Scheuerman as a good example of how to manage this thin line. As he points out, King's "civil disobedient stood on the side of "law and order', even accepting punishment by segregationist judges and racist juries. They claimed that they were representing the true legality, and by doing so they forced important reforms. Be it as it may, it remains quite unclear how civil disobedience could be articulated in the European context. Although it is very clear that extralegal power has gained momentum through the new European crisis management, it is hard to imagine how the peoples of Europe could use civil disobedience in this context. To some extent, it seems more likely that the reaction may come from less bright corners of the European ideological landscape.

Mikkel Thorup's contribution looks at the political imaginary of the emerging populist, anti-Muslim, right-wing movements in Europe in the search for answers on how to un- 
derstand the political reactions to the European crisis. As he points out, these movements are informed and fed by feelings that are similar to those which were common for the anti-modernist movements of the interwar period: the sense of decay, resentment for descending status, the picture of a loss of supreme values and respect for authority. While anti-modernism as an ideological figure remained largely an intellectual movement at that time, new emerging forms of right-wing politics succeeded in articulating popular emotional anxieties towards migration with the intellectual anti-modernist discourse. If Jews were the object of hatred in the past, now the Muslims assume this role. Further, European elites become part of the problem since they are seen as the source of European weakness towards the alien threat. The darkness of these developments lies in the fact that the "democratization of reaction" made this movement able to talk to all those who perceive themselves as losers of the integration process. Moreover, they are not few, given the elitist, undemocratic and exclusionary dynamics of today's European governance.

The final question arising from all contributions may be condensed and explained in the quest for constitutional reform in Europe. As put by Kjaer and Olson in their concluding remarks, the European project was the result of the bitter experiences of Europe in the aftermath of the two Great Wars. It has been constitutionalized in the legal structures of an ever-closer union mainly integrated through law and economics. The EU's constitutional structures seem however to have overreached its own capacities of advancing the project, giving place to a structural dissonance of the social processes going on in different social settings and the institutional structures of governance that demand a reconceptualization of the underlying constitutional project. On whether this is going to happen or not, depends the future of the whole project.

In the end, the book provides a very convincing picture of the challenges facing Europe and Europeans today. It makes a strong argument for a conceptualization of these challenges that goes far beyond one specific and sectorialized crisis. This is not only a crisis of the Euro. This is not only a crisis of the "rule of law". There is not a political crisis caused by new populist and racist movements. There is an European constitutional crisis awaiting to be tackled. This diagnosis restates the theoretical and conceptual position of "crisis" as a turning point in history where decisions are to be made. "Crisis is back". As a consequence, Europe needs a new constitutional decision. Hopefully, this time a democratic one.

\section{References}

Elchardus, M., \& Spruyt, B. (2014). Populism, Persistent Republicanism and Declinism: An Empirical Analysis of Populism as a Thin Ideology. Government and Opposition, 51(1), 111-133. https://doi.org/10.1017/gov.2014.27

Koselleck, R. (2006). Crisis: Reinhart Koselleck. Journal of the History of Ideas, 67(2), 357400.

Luhmann, N. (1997). Die Gesellschaft der Gesellschaft. Frankfurt: Suhrkamp. 
Thornhill, C. (2011). A Sociology of Constitutions: Constitutions and State Legitimacy in Historical-Sociological Perspective. Cambridge: Cambridge University Press. 